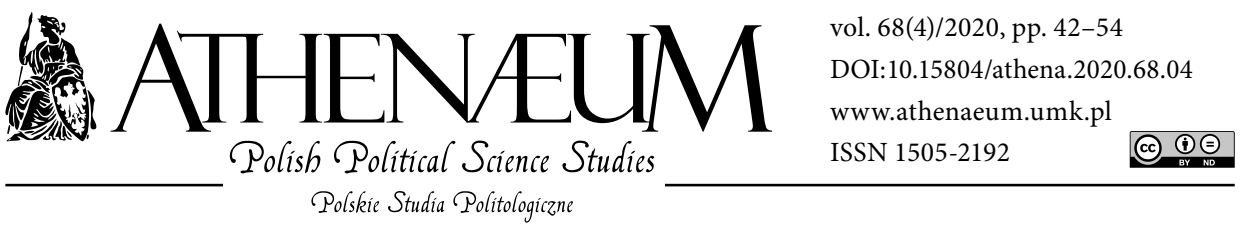

\title{
THREATS TO PUBLIC SAFETY ON THE EXAMPLE OF BASQUE NATIONALISM IN SPAIN
}

\author{
ZAGROŻENIA BEZPIECZEŃSTWA PUBLICZNEGO \\ NA PRZYKŁADZIE NACJONALIZMU BASKIJSKIEGO W HISZPANII
}

Justyna Lubańska-Gómez*•

\begin{abstract}
This article outlines certain dangers related to extreme attitudes of ethnic groups on the example of terrorism in the Basque Country. It shows how aggression was born in this Autonomous Community of Spain and what actions and attitudes of Spanish authorities enhanced it. It demonstrates how Francoist repressions strengthened separatist tendencies in this region. The Basque Country example reveals that persecution does not provide a solution to the problem. Just as every action causes reaction, aggression causes aggression. Government repressive measures can lead to the birth of a false myth, where a terrorist organization takes the role of the defender of the rights and freedoms of society. The will for peace, effective communication and the dialogical approach are values that provide security and peaceful coexistence of society.
\end{abstract}

Keywords: Basque nationalism; Spanish regionalisms; ETA terrorism; GAL revanchism

\footnotetext{
* Nicolaus Copernicus University in Toruń.
}

W artykule nakreślono niektóre zagrożenia związane ze skrajnymi postawami grup etnicznych na przykładzie terroryzmu w Kraju Basków. Autor ukazuje, jak narodziła się agresja w tej hiszpańskiej Wspólnocie Autonomicznej oraz działania i postawy hiszpańskich władz, które ją wzmocniły. Opisuje również, jak represje frankistowskie wzmocniły separatystyczne tendencje w tym regionie. Przykład Kraju Basków pokazuje, że prześladowania nie zapewniają rozwiązania problemu. Tak jak każde działanie wywołuje reakcję, tak agresja wywołuje agresję. Rządowe środki represyjne mogą prowadzić do narodzin fałszywego mitu, w którym organizacja terrorystyczna przyjmuje rolę obrońcy praw i wolności społeczeństwa. Wola pokoju, skuteczna komunikacja i podejście dialogowe to wartości, które zapewniają bezpieczeństwo i pokojowe współistnienie społeczeństwa.

Słowa kluczowe: nacjonalizm baskijski; hiszpańskie regionalizmy; terroryzm ETA; rewanżyzm w działaniach GAL 
Dialogue is a protection against irresponsible recognition as fundamental of those truths which often result from everyday life, moments, circumstances and are not absolute and universal at all (Szulakiewicz, 2003, p. 57)

Is Spain a nation? Its historical and political fate is so complex and wide-ranging that the answer to this question is not easy. Explaining the issue of national identity in no Western European country has caused (and causes) as many problems as in case of Spain. It was the source of civil wars in the nineteenth and twentieth centuries - not directly their main cause, but it largely antagonized Spanish society.

The fall of Francoism and the peaceful democratic transformation begun in the mid-1970s, stimulating public and political debate on the subject. General Franco's dictatorship, introducing the unicultural identity by force, manipulated Spanish nationalism and contaminated the national symbols. From then on, it became associated with authoritarianism. Today, the discussion about the nation and nationalism is undertaken in the shadow of the worldview imposed by Francoism, leading to serious disputes and conflicts. Political attempts to manipulate the concept of the nation delay the chances of finding a consensus.

The Spanish Constitution of 1978 builds on the unsolvable unity of the Spanish people, recognizing and guaranteeing the right to autonomy of the nationalities and regions that are part of the state and ensuring solidarity between each of them (Spanish Constitution, 1978, p. 3). Castellano (Castilian) is the official language of the state, used as customary by most Spaniards. All Spaniards must know it and have the right to use it. The other languages: Catalan/Valenciano, Gallego, Euskera/Vasco, Aranés, are also official in the respective Autonomous Communities, according to their statutes. Spain's linguistic wealth is its national heritage, a subject of special respect and protection (Spanish Constitution, 1978, p. 3).

The constitution respects Spanish cultural diversity, emphasizing that it is an inseparable feature of the country. Cultural diversity and local identity are special values in Spain, especially if we look at them from the point of view of regionalisms. A large proportion of the inhabitants of the Basque Country, Catalonia and Galicia compare their sense of belonging to the country with their local identity, that is, they feel Spanish because the Autonomous Community they live in is part of Spain.

A poll conducted by the Catalan Institute of Political and Sociological Sciences in 2020 shows that $38.4 \%$ of respondents feel as much Spanish as Catalan, 
23.8\% more Catalan than Spanish, 21.1\% exclusively Catalan, 7.7\% exclusively Spanish (Sondeig d'opinió Catalunya, 2020, p. 25). A similar survey carried out in the Basque Country in 2019 revealed that $38 \%$ of the community consider themselves Basque and Spaniard equally, and $25 \%$ of the population identify themselves more with Basque than Spanish nationality. Only 4\% see themselves solely as Spaniards and 26\% as purely Basques (Euskobarómetro, 2019, p. 49).

Extreme regionalists recognize that Spain is a nation of nations and regions. The definition of national identity is shifting from centralist Spanish towards counter-hegemonic formulas, where what is Spanish is seen as "foreign", as an antithesis of what is Basque, Catalan, or Galician (Jordan \& Morgan-Tamosunas, 2000, pp. 4-5).

The Basque Country is one of regions most at odds with the central government in Spain. In this region, moderate nationalism is intertwined with extreme nationalism and even separatism. There are echoes of the terrorist organization ETA both inside Spain and abroad. It is worth taking a closer look at the situation of the Basque Country and the reasons for the failure of negotiations between the central and local authorities.

It is interesting that Basque nationalism, unlike, for example, Catalan, has no historical justification, it is based on a myth - the Basque Country has never had political independence, since the early Middle Ages it was integrated with the Castilian monarchy (Sobek, 2007, pp. 129-130).

Basque nationalism was born in the nineteenth century during the wars for the succession of the Spanish throne, it was officially a form of opposition to the narrowing of fueros (political privileges), persecution and linguistic discrimination. Euskera's origin (a language used by the Basques), is still not obvious, it is associated with Romance languages, but there are also theories about AfroAsiatic and even Caucasian roots, relating to Georgians and Armenians (Nuño, 2019).

It was the defense of fueros and Euskera that became the basis of nationalism. Its author was Sabino Arana Goiri, who recognized that the Basque Country has all the characteristics of a nation: race, language, government, laws, customs, and historical personality. Properly interpreted history of the age-old Basque-Spanish struggle completed Arana's vision (Peda, 2004, p. 212).

Economic reasons became the main cause for the gradual separation. Basque nationalism was also a response to modernization and progress. Rapidly progressing industrialization and urbanization processes resulted in the appearance of a very rich bourgeoisie and an influx of immigrants (especially to the Vizcaya 
province). Craftsmen, small entrepreneurs felt trapped by the great capital of the nouveau riche and a wave of new industrial workers. The vision of a decline in the social ladder filled them with fear and drew attention to Arana's views (Balfour \& Quiroga, 2007, pp. 231-232).

The beginning of the twentieth century, marked by the economic and political crisis, contributed to the evolution of Basque separatism against the central government of Spain. Initially, the carrier of nationalist views was the Basque Nationalist Party PNV (Partido Nacional Vasco). In the 1930s, it transformed into the main political party of Euskadi, appropriated the symbols of the Basque Country - the anthem and the flag. The remaining political parties, regardless of the political option represented (socialist, republican, conservative), remained faithful to national symbols (Balfour \& Quiroga, 2007, p. 237).

The outbreak of the Spanish Civil War stopped the process of gradual privileging of the Basque Country by the Second Republic. From 1936, Basque nationalists identified themselves with the anti-Francoist struggle, thus gaining respect at the national and international level. To gain social legitimacy, they armed themselves with anti-fascist slogans supporting republican Spain. This attitude and the revanchist policy of the Francoists became a powerful catalyst for Basque nationalism. Some argue that nothing has helped Basque nationalism so much as the Francoist repression (Balfour \& Quiroga, 2007, p. 238).

The victorious camp with general Francisco Franco made an attempt to eliminate all manifestations of nationalism in Spain (including Basque integrity). During almost 40 years of dictatorial rule, he led a dynamic process of national assimilation, making the symbols of Basque culture and identity illegal. The Francoist program proclaimed that "Spain is the unity of the nation's destiny. [...] All separatism is a crime that we will not forgive" (Dobrzyński, 1975, p. 76). Tough politics backfired - it caused a rapid revival of the Basque national consciousness. What Sabino Arana Goiri's propaganda and PNV's actions have been slowly achieving for decades, Generals Mola and Franco achieved in a few months - the awakening of the Basque national consciousness and the will to resist (Clark, 1979, p. 76).

The result of the Francoist terror was the creation in the $1950^{\text {s }}$ of an organization called ETA (Euskadi Ta Askatasuna), which influenced the history of both the Basque Country and the entire Spain. The beginnings of its activity date back to $1952-1953$, when young students and intellectuals began organizing meetings where they were expressing their dissatisfaction with the brutality of the Franco's dictatorship and the lack of firm opposition to it. They manifested their 
disappointment with the overly lenient policy pursued by the Basque Nationalist Party (PNV). The following activists stood out among the participants: Julen de Madariaga, Alfonso Irigoien, José Manuel (Manu) Aguirre Bilbao, José María Benito del Valle, Iñaki Gainzarain, José Luis Álvarez Enparantza (Txillardegi), Iñaki Larramendi, Rafael Albizu. They formed the Ekin group (“do", “act"), considered the predecessor of ETA. The final separation from PNV in 1958-1959 marked the beginning of an organization called Euskadi Ta Askatasuna - ETA (Basque Country and Freedom). The official date of its creation is considered to be July 31,1959 . At the beginning it was patriotic and nationalistic organization, paying attention to the respect of traditional Basque values. Gradually, however, the program evolved, becoming more and more radical (Segura, 2009, pp. 21-22).

The ideological source of ETA was Zionism, the National Liberation Front in Algeria, the Chinese and Cuban Revolutions, the Vietnam War, and the Irish IRA. The founders also used the reflections and remarks made by Federico Krutwig in a book published in 1963 entitled Vasconia, combining Basque nationalism with Marxism (Segura, 2009, p. 23). This way, quite late, after several years of the organization's existence, the theoretical foundations were created: the Basques are a just, democratic nation, supporting freedom and a clear historical path, which was taken over by Spain - a backward and almost feudal country, negating Basque individual and national rights, inhibiting its cultural and economic development. All misfortunes currently affecting the Basque Country are being provoked solely and exclusively by the occupying country. Consequently, the only way to return to a state of happiness and to regain the freedom is to fight for the independence of the Basque Country (Jáuregui, 2000, pp. 206-207).

The beginning of the $1960^{\text {s }}$ was marked by the first ETA actions that determined its character and methods of operation. Activists undertook preliminary anti-Francoist and pro-nationalist operations: the graffiti with Gora Euskadi ("up with the Basque Country"), hanging the Basque flag (ikurrina), burning the Spanish flag hanging on the Delegation building in Guipúzcoa and finally the first terrorist act - attack on a train carrying Francoist supporters intending to celebrate the anniversary of the military uprising of July 18 (the beginning of the Spanish Civil War of 1936-1939) in San Sebastián. This last action ended in failure, several dozen nationalist fighters, not only from ETA, were arrested (Segura, 2009, p. 23). In the late $1960^{\text {s }}$ and 70s, ETA became totally radical, for example, the secret police chief Melitón Manzanas was killed, a car carrying Prime Minister Carrero Blanco (general Franco's closest associate) was blown up (Olmo, 2018). 
The actions of ETA met with the reaction of the Francoist authorities, which intensified the persecution and repression of ETA members, often affecting civilians not politically involved. Joseba Elósegui, a participant in the Spanish Civil War of 1936-1939, tried to show to the world the desperate situation of the Basque nation. He made a public self-immolation in San Sebastián (Crespo, 2011). General Franco's actions had a harmful effect on Spanish regionalisms: resulted in the formation of a nationalist subculture antagonistic to the government.

The death of Francisco Franco at the end of 1975 brought the Basque Country hope for change and easing the tense situation in the region. Entering the democratic path of change (la transición democrática) brought the new conciliatory approach to nationalisms. The government was ready to make a series of concessions to ease the internal situation in Spain.

The extensive autonomy was granted to the Basques. Its range was close to the special privileges - fueros. In 1976, the public demonstration of national symbols was allowed, and Euskera was recognized as an official language (along with Castilian). The status of the Autonomous Community was approved in a referendum of 1979. Bizkaia, Alava, Guipúzcoa were included, but Navarra did not join (Sobek, 2007, p. 134). The Basque Country has received more privileges and powers than any other ethnic minority in Spain.

The considerations bestowed upon the Basques during the democratic transformation did not satisfy ETA. During 20 years of its existence, the organization has not achieved internal unity, it has not been able to develop its program in a more political than military direction. With the internal heterogeneity of ETA, it was difficult for the government to conduct an effective debate. The conciliatory policy of the authorities was not able to change the hard and aggressive position of some ETA activists, who were striving not towards autonomy but independence, putting forward demands that the central government could not fulfill.

While in the $1960^{\text {s }}$ and $70^{\text {s }}$ ETA had the relative support of the Basque society experiencing repression and persecution of the regime, after 1975 it began to gradually lose the Basque's approval. The organization did not show any willingness to dialogue or discuss with the government, going underground and continuing its brutal activities (Reverendo López, 2006, p. 5).

During the years of intense dialogue between the government and Basque society, the separatists from ETA continued the struggle, not fully understanding for what or against what or whom. Eventually, Francisco Franco and his 
dictatorship fell - the greatest enemy ceased to exist, taking away the legitimacy and sense of the organization's operations. Meanwhile, from 1976 to 1980, 261 people were killed as a result of ETA aggression (Segura, 2009, p. 388).

After 1975, the party willing to dialogue and concessions was PNV. In 1975, it gave its support to the anti-Francoist Democratic Platform (Platforma Democrática) led by the socialists from PSOE (Partido Socialista Obrero Español). PNV also updated its election program, replacing the outdated Euskadi definitions with the slogans of democracy, immigrants integration into Basque society. The changes brought its success: in 1980 it transformed into the main political party of the Basque Country (Balfour \& Quiroga, 2007, pp. 241-242).

When the Autonomous Statute came into force, PNV, by entering into a coalition with various political groupings, relatively assisted the process of democratization in Spain and the regulation of relations between the Basque Country and Madrid. At the same time it supported the development of culture, sport and the Basque language (Balfour \& Quiroga, 2007, pp. 250-251).

Meanwhile, from the late $1970^{s}$ ETA intensified terrorist activities. Violence on this scale was unexpected: 66 victims in 1978, 76 in 1979, 92 in 1980. It also introduced a new way of financing: collection of a "revolutionary tax" from Basque and Navarre entrepreneurs. In order to regain public support, ETA participated in the campaign against the construction of the nuclear center in Lemóniz. The beginning of the $1980^{\text {s }}$ was also a period of attacks against members of the Spanish army in order to destabilize it. ETA leaders realized that the introduction of democracy was a threat to the organization, as it deprived it of its sense of existence. And the adoption of the Constitution in 1978 and the Autonomous Statute meant that no one in the international arena had doubts about the authenticity of democracy in Spain. That is why the years 1976-1981 were the most difficult and brutal - ETA was able to commit one attack every two days and one murder every five days (Segura, 2009, p. 92).

Basque separatism had a negative impact on the young Spanish democracy. The crimes of ETA, destabilizing the country, were one of the causes of the coup détat of February 23, 1981. It was organized by members of the military and civil guard supporting the Francoism. The attack was unsuccessful. A day later, Juan Carlos organized a meeting of representatives of political parties, with the exception of Basque and Catalan nationalists. He called on the audience to reflect on the actions taken, to maintain unity and peace in Spain (Segura, 2009, p. 96).

When the organization was dissolved in 2018, it was leaving behind the bloody history of its activities, with 854 assassinated - according to the website 
of the Ministry of the Interior, most of them Basques; 79 kidnapped (12 of them murdered), and 6,389 wounded. 197 cases are pending clarification (170 are dismissed and 27 archived) (Ormazabal \& Aizpeolea, 2018).

The Spanish authorities tried to revenge against the ETA terrorists. In 1982, the socialist PSOE came to power and started the fight against Basque separatists applying methods similar to those used by ETA. A dirty war (guerra sucia), which is worth a more detailed explanation, began, led by the Anti-Terrorist Liberation Groups GAL (Grupos Antiterroristas de Liberación).

The fighting methods used by the GAL were attacks, kidnappings, torture, and killings of ETA fighters in the south of France. In fact, the dirty war had begun earlier, between 1975 and 1981, during the government of Carlos Arias Navarro and Adolfo Suárez. GAL's main actors were: Triple A, National Spanish Action ANE (Acción Nacional Española), and Spanish Basque Battalion BVE (Batallón Vasco Español). These groups were assisted by far-right fighters, French and Italian neo-fascists. Triple A is estimated to have committed five attacks on Euskadi, ANE one, BVE twenty-two, other organizations or uncontrolled citizens - ten. Activities on the border with the law and outside it allow us to assume that there was a relatively clear system of coordination and control, reaching specific units of the state security system, although perhaps without the consent of the political authority. In any case, many families, not necessarily with extremely nationalist views, still remember the dozens of victims murdered during the first reign of the democratic transformation, whose authors have never been convicted (Segura, 2009, pp. 116-117).

Undoubtedly, it was the Spanish government-backed GAL fighters with twenty-seven killings that took the most brutal fight against ETA. The head of the civil guard, General José Antonio Sáenz de Santamaría, the model of the Francoist militant, who joined the ranks of power during la transición democrática, openly and honestly admitted that the fight against terrorism exceeded judicial and institutional boundaries, as it required direct action: "The rule of law is fine, but it cannot be taken to its ultimate consequences because we would be left in the hands of the terrorists" (2001, as cited in: Garzón Lozano, 2005, p. 176).

One of the reasons for these "direct actions" of the GAL was to force the French government to take a clear position against the ETA terrorists who were organizing attacks in France (later carried out in Spain). There were more reasons why the organization was founded, however the top priority was of course the fight against ETA terrorism. Initially, there was little interest in the origin of the organization. Once the press got involved in solving the GAL puzzle, the 
scandal broke out. It was suspected that the state was financing the organization's actions. As justified by the historian Charles Powell, the attitude of social disengagement in crimes committed by the GAL was not only an expression of a civic participation, but also, for how long the victims of GAL were supporters of ETA, was a sign of acceptance of the methods that brought results. Attacks against ETA continued even in 1987, when the first phase of the most important peace negotiations between the government and Basque terrorists was carried out (Mesa de Argel) (Garzón Lozano, 2005, p. 182).

Italian and French mercenaries, as well as Latin American members of parapolice groups, worked for the GAL. Units from the circles professionally involved in crime and organized crime were employed and well paid. Only a small part of them were arrested in France, Spain or Portugal, others were never caught by the judiciary. The first GAL actions took place in October 1983, they were performed on possible ETA members José Ignacio Zabala “Joxi” and José Lasa Arostegui "Joxean". The murders were carried out by shot to the head, the bodies were not found until twelve years later, buried in lime, in unused areas of Alicante (Garzón Lozano, 2005, pp. 182-183).

When the press became interested in the case, a scandal threatened the government, as it turned out that high-ranking state officials were involved in the dirty war. In 1988, one hundred and four specialists, intellectuals and lawyers presented to the National Assembly a complaint against Deputy Commissioner José Amedo and Inspector Michel Domínguez from Bilbao for maintaining contacts with the GAL. The trial took place in the summer of 1991 with the active participation of the press and the judiciary. The police members who gave testimony were replying evasively to the questions: "I don't know", "I don't remember", "I'm not going to answer". Analysts and politicians, on the other hand, were avoiding answering to the questions, referring to the raison d'état. Ultimately, Amedo and Domínguez were convicted of only one attack. In the 1990s, a dozen or so high-ranking state officials were convicted for cooperation with the GAL (Garzón Lozano, 2005, pp. 184-190).

The exposure of the GAL scandal is due to the persistence and pressure of some judges (such as Baltasar Garzón), who, under the pressure of the mass media and the opposition wishing to strengthen their electoral chances (hoping to undercut Felipe Gonzalez's charisma), took decisive steps to reveal the truth about the GAL. The PSOE board was denying the evidence and tried to defend some of the accused suspects. This attitude of socialist politicians allowed to develop speculations about their connections with the organization. The right- 
wing Partido Popular focused on weakening Gonzalez's position, accusing him of lack of interest in solving the issue of the so-called first dirty war waged since the mid-1970s. A possible disclosure of the commitment of the government of Adolfo Suarez to guerra sucia could call into question la transición democrática, which is considered a success of Spain. The country was in chaos and nationalisms and ETA took advantage of it. As a result, the GAL helped the Basque terrorists, serving as an excuse for continuing terrorist activity (Segura, 2009, pp. 125-126).

It is also worth mentioning the role of the press in discovering the origin and judging the GAL. A journalistic investigation was initiated by the Basque daily Deia. The investigation was continued by the newspaper Diario 16 . The journalist most involved in explaining the GAL problem was Ricardo Arques (initially collaborating with Melchor Miralles). During the gradual disclosure of the facts by Diario 16, its director, Pedro J. Ramírez, was dismissed. Further journalistic investigations were conducted by El Mundo, by the aforementioned Pedro Ramirez. The story of the successive unmasking of the GAL and attempts to prove the discovery of the truth resembled the scenes seen on the big screen. And in fact, it served to write the script of the film called GAL (Arques, 2006).

Part of the GAL crimes contributed to the birth of Basque revolutionary heroes, making some ETA activists more special than they really were (the case of the murder of Mikel Goikoetxea - ETA activist with no special achievements for the organization, who, thanks to the death sentence issued by GAL, passed into the ranks of the ETA symbol). Additionally reminding about the victims of Francoist repression and crimes during the Civil War of 1936-1939, including the bombing of Guernica, made ETA activists martyrs for the freedom of the Basque Country, thereby justifying the crimes they were committing (Segura, 2009, p. 131).

The discrepancy between the Basque national symbolism and the emblems of Spain remained a problem that was difficult to solve during the democratic transformation. In contrast to Catalonia celebrating a new beginning and gained autonomy, the Basques emphasized the connection of old Spain with the new one. The sense of connection between Francoism and the methods used by the dictatorship and the democratic system was increased by the state terrorism of the $1980^{\text {s }}$ (GAL). The actions of the Spanish authorities convinced some Basques to the separatist theory that the new system was not much different from the Franco dictatorship (Woodworth, 2005, pp. 412-413).

Basque nationalism introduced an idealized version of the past in the region. Historical nostalgia was deepened by a series of rituals performed in the name 
of the honor of deceased ETA members, considered heroes who gave their lives for their homeland. Their memory is still honored today by singing stories and dancing (mainly in small towns and villages where support for extreme nationalists is the highest). These efforts are accompanied by a symbolic representation of Euskal Herria: flags, hymns, maps. Ritual ceremonies glorifying violence and sacred emblems of Basque nationalism can be described as a "political religion" where the nation has become a substitute for the Catholic God (especially in Guipúzcoa) (Balfour \& Quiroga, 2007, p. 257).

Extreme Basque patriots, socialists and post-communists still continue to fuel the memory of history. The Basque government organizes dozens of shows devoted to the Spanish Civil War 1936-1939 and preserving the memory of the Basque nationalists of the republican era: the celebration of the anniversary of the establishment of the first Basque government in 1936, the organization of the Basque army, the bombing of Guernica (Balfour \& Quiroga, 2007, pp. 258-259).

The discrepancy between what is Spanish and Basque applies to both history and symbolism. The Basque left wing accepted the monarchy and the Spanish flag in the age of democratic transformation as a compromise that will make the old system end sooner. Ikurriña became an anti-Francoist emblem, legalized after 1975. The Spanish flag for some Spaniards (not only nationalists, but also in regions such as the Canary Islands, Asturias, Andalusia) is associated with Francoism. The identification of the Spanish flag and anthem, in the sphere of national identity, is evidence of the domination of the symbols over words (Galán, 2006).

Probably what unites Spaniards more than national emblems is international success of native artists, singers and sports teams, which brings them pride and sense of community (Balfour \& Quiroga, 2007, p. 261).

As we can see on the example of the Basque Country, a sense of regional identity in Spain is its wealth and treasure, but in extreme form it can destabilize Spanish society. Extreme behavior that leads to aggression is always a threat to public safety. The modern history of the Basque Country clearly shows that violence and repression are not the solution to the problems, it only generates new conflicts. Francoist repressions provoked ETA terrorism. ETA terrorism awakened government revanchism (GAL). Aggressive actions caused aggressive reactions and led to further conflicts. Its consequences affected the civilian population, causing a loss of sense of security and arousing a distrust towards the authority. 
Dialogue and moderation are the basis of social security and public order. It requires the will to communicate across divisions, for the common good. Peaceful actions based on dialogue have a real impact on public security. Just as every action provokes a reaction, aggression causes aggression. "A properly understood dialogue weakens the universalistic (fundamentalist) claims of the individual $[\ldots]$. The philosophy of dialogue shows that dialogue [...] is something more. Dialogue means the area where thoughts arise, it gives a new quality of thinking, it is a philosophy in action" (Szulakiewicz, 2003, p. 55). Dialogical thinking gives the opportunity to find new ideas and solutions. It allows openness to what is new and different (Szulakiewicz, 2003, pp. 56-57). This approach fosters the order and security of the individuals and the entire society.

\section{ReFERENCES:}

Arques, R. (2006, November 19). La verdad sobre el GAL. El Diario Montañés. Retrieved from: http://www.eldiariomontanes.es/prensa/20061119/opinion/verdadsobre_20061119.html.

Balfour, S., \& Quiroga, A. (2007). España reinventada. Nación e identidad desde la Transición. Barcelona: Ediciones Península.

Clark, R.P. (1979). The Basques, the Franco Years and Beyond. Reno: University of Nevada Press.

Crespo, M. (2011, January 21). Quemarse a lo bonzo: los orígenes de un desesperado acto de protesta. El Mundo. Retrieved from: https://www.elmundo.es/ elmundo/2011/01/21/internacional/1295626707.html.

Dobrzyński, R. (1975). Błękitne imperium gen. Franco. Warszawa: Książka i Wiedza.

Euskobarómetro (2019). Estudio periódico de la opinión pública vasca. Universidad del País Vasco. Retrieved from: https://www.ehu.eus/documents/1457190/1525260/ EB_int_Junio19.pdf/25ff5c39-0988-d46e-a028-d5b688693cf1?t=1563537212000.

Galán, L. (2006, May 14). La marca España pierde entre los jóvenes. El País. Retrieved from: http://www.elpais.com/articulo/espana/marca/Espana/pierde/jovenes/ elpepunac/20060514elpepinac_16/Tes.

Garzón Lozano, L.E. (2005). El combate al terrorismo y la guerra sucia en España: el caso de los Grupos Antiterroristas de Liberación (GAL). In: P. Salazar Ugarte (ed.). El poder de la transparencia: seis derrotas a la opacidad (pp. 175-217). México: UNAM, Instituto de Investigaciones Jurídicas. Retrieved from: https://archivos. juridicas.unam.mx/www/bjv/libros/4/1665/8.pdf.

Jáuregui, G. (2000). ETA: orígenes y evolución ideológica y política. In: A. Elorza (ed.). La historia de ETA (pp. 171-276). Madrid: Temas de Hoy.

Jordan, B., \& Morgan-Tamosunas, R. (eds.) (2000). Contemporary Spanish Cultural Studies. London: Arnold. 
Nuño, A. (2019, June 5). ¿Casualidad u origen común? La sorprendente historia del euskera. El Confidencial. Retrieved from: https://www.elconfidencial.com/almacorazon-vida/2019-06-05/pais-vasco-euskera-historia-idiomas-lenguas_2055066/.

Olmo, G.D. (2018, May 4). 7 momentos para entender qué fue ETA, el grupo armado que quiso separar al País Vasco de España y Francia. BBC Mundo. Retrieved from: https://www.bbc.com/mundo/noticias-internacional-43985393.

Ormazabal, M., \& Aizpeolea, L.R. (2018, May 3). ETA anuncia su disolución. El País. Retrieved from: https://elpais.com/politica/2018/05/03/actualidad/ 1525336524_523980.html.

Peda M. D. (2004). Narodziny nacjonalizmu baskijskiego. Międzynarodowy Przegląd Polityczny, 2, 201-213.

Reverendo López, L. (2006). El binomio nacionalismo terrorismo. El caso del País Vasco. Mexico: Universidad de las Américas Puebla. Retrieved from: http://catarina.udlap. $\mathrm{mx} / \mathrm{u}$ _dl_a/tales/documentos/lri/reverendo_1_l/capitulo_2.html.

Segura, A. (2009). Euskadi. Crónica de una desesperanza. Madrid: Alianza Ensayo.

Sobek, U. (2007). Tendencje nacjonalistyczne we współczesnej Europie na przykładzie Kraju Basków. Zeszyty Naukowe Zakładu Europeistyki WSIiZ w Rzeszowie, 1, 127-150.

Sondeig d’opinió Catalunya (2020). Institut de Ciències Polítiques i Socials, Barcelona. Retrieved from: https://www.icps.cat/archivos/sondeigs/sc2020nacespcat. pdf?noga=1.

Spanish Constitution of 1978, BOE-A-1978-31229 (1978). Retrieved from: https://www. boe.es/buscar/pdf/1978/BOE-A-1978-31229-consolidado.pdf.

Szulakiewicz, M. (2003). Myślenie dialogiczne w poszukiwaniu nowej filozofii pierwszej. In: M. Szulakiewicz, \& Z. Karpus (eds.). Dialog w kulturze (pp. 41-66). Toruń: Wydawnictwo Uniwersytetu Mikołaja Kopernika.

Woodworth P. (2005). Dirty War, Clean Hands: ETA, the GAL and Spanish Democracy. New Haven, CT: Yale University Press.

\section{Diaries, newscasts:}

BBC Mundo (https://www.bbc.com/mundo)

El Confidencial (https://www.elconfidencial.com/)

El Diario Montañés (https://www.eldiariomontanes.es/)

El Mundo (https://www.elmundo.es/)

El País (https://elpais.com/) 